\title{
Transit in the 2000s: Where Does It Stand and Where Is It Headed?
}

\author{
Michael Manville, Brian D. Taylor, and Evelyn Blumenberg \\ UCLA Luskin School of Public Affairs
}

\begin{abstract}
U.S. public transit has experienced something of a renaissance in the 2000s, with per capita service levels increasing nationwide and public investment growing even faster-particularly expenditures on rail transit. Despite this expansion, overall transit patronage has been relatively flat, and has declined significantly since 2014. What is behind these trends, and what do they portend for the future of transit? In this paper we consider three challenges shaping transit today and in the years ahead: (1) the asymmetry of transit supply and use make it especially vulnerable to changes and disruptions; (2) many of the factors that determine transit ridership, such as levels of private vehicle ownership and use, are largely beyond the control of transit agencies; and (3) there remains no consensus about what purpose transit should serve-politically the industry thrives on the idea that it will reduce congestion or clean the air, while in practice it primarily moves poor people, a very different and sometimes conflicting role. How successfully transit systems manage each of these challenges will shape their future roles and significance.
\end{abstract}

\section{Overview}

Public support for transit investment, along with transit investment itself, is strong in the United States. But patronage is faltering and the recent decline in transit use has stirred considerable concern in the media and among transportation professionals. Figure 1 shows the indexed trends since 2000 in ridership, ridership per capita, inflation-adjusted public investment, and service hours. Following steady growth in ridership through the mid-2000s, transit use slipped during the Great Recession beginning in 2008. Like the economy, transit patronage gradually recovered between 2010 and 2014. But unlike the U.S. economy, which has continued to slowly recover, transit use-and particularly per capita transit use-began falling again in 2014. Observers point to all manner of culprits for these trends, ranging from falling gasoline prices to the rise of transportation network companies like Uber and more.

(C) 2018 Michael Manville, Brian D. Taylor, and Evelyn Blumenberg

http//dx.doi.org/10.5038/2375-0901.21.1.11

ISSN: 1077-291X | Licenced under Creative Commons License Attribution - Noncommercial 4.0

The Journal of Public Transportation is published by the Center for Urban Transportation Research

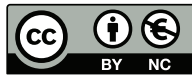
at the University of South Florida 


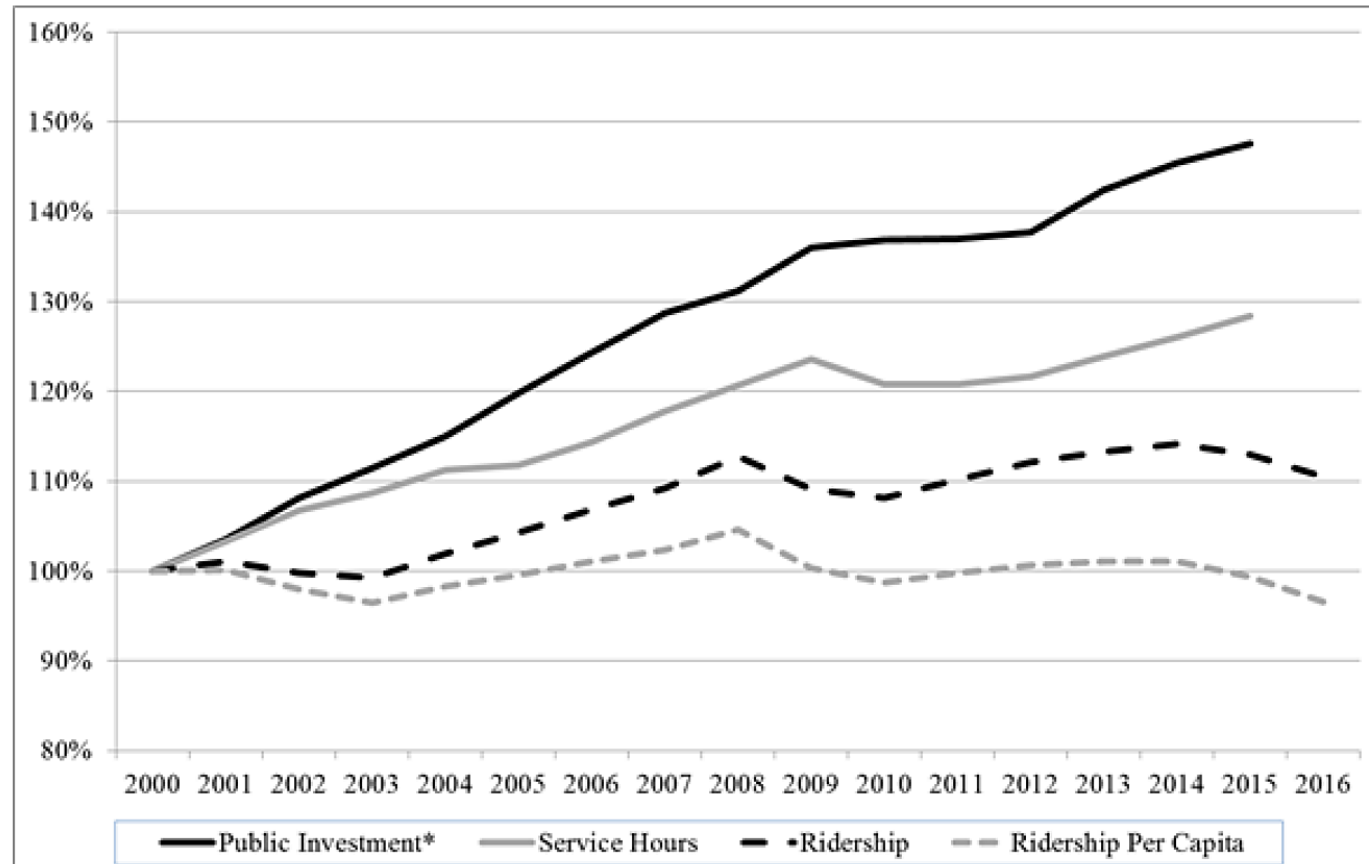

*Public Investment $=$ Operating Expenses +10 -Year Moving Average of Capital Expenditures Source: (a) National Transit Database, 2000-2015; (b) American Public Transportation Association, Ridership Report (c) U.S. Census Bureau, National Intercensal Tables.

\section{FIGURE 1.}

Indexed Trends in Transit Ridership, Ridership per Capita, Inflation-Adjusted Public Investment, and Service Hours since 2000

Figure 1 also shows the indexed trends in inflation-adjusted public transit investment (operating expenditures plus a 10-year moving average of capital expenditures) and transit vehicle service hours. These trends paint both an auspicious picture of an industry that has attracted significant public support and largesse, and a sobering picture of an industry that attracts funding more easily than customers. Inflation-adjusted expenditures are increasing considerably faster than service, while service is increasing considerably faster than overall patronage, while per capita ridership is down since 2000. Although this figure plots investment in and service provided by all transit modes, rail transit (subways, commuter rail, and especially light rail) has proven especially popular in recent years with public officials and the people who elect them. In 2000 light rail transit accounted for $6.3 \%$ of all transit investment nationwide and carried 3.6\% of all transit trips, but by 2015 these shares had increased to $9.1 \%$ of all public transit investment and 5.1\% of trips (National Transit Database $2000 \& 2016){ }^{1}$

Transit's ridership issues are not confined to the past few years. Figure 2 shows a longer time trend in both per capita transit trips and transit service supply, the latter measured by per

\footnotetext{
${ }^{1}$ Transit investment is comprised of operating expenditures for a given year plus a 10 -year inflation-adjusted moving average of capital expenses leading up to that year. The 10-year moving average takes the given year as the midpoint ( 5 years before, current year, 4 years after). For years 2011 and after, the 10 years shrink down to 9, 8, 7, 6, and finally to a 5 -year moving average, because 2015 is the endpoint.
} 
capita vehicle hours of service. Here we see a troubling pattern: a steady increase in transit service supply (which has tripled since 1970) matched by an at-best flat trend in per capita ridership. This pattern of rising service levels and generally flat patronage is not simply an artifact of aggregating to the national level. Places that have aggressively added transit service have not necessarily seen surges in ridership. Since 1985, for example, Los Angeles County has spent billions of dollars to go from having no rail service to having over 100 miles of rail lines today. But ridership on LA Metro, the agency that made these investments and that accounts for the vast majority of county transit use, peaked absolutely in 1985, when the county had almost two million fewer people. From 1985 to 2015, LA Metro ridership fell 25\% per capita (National Transit Database 2017; U.S. Census Bureau 2016). This combination of rising supply and relatively flat ridership has made transit steadily less productive over time as people have been using it less per inflation-adjusted dollar spent on it (Taylor and Morris 2015).

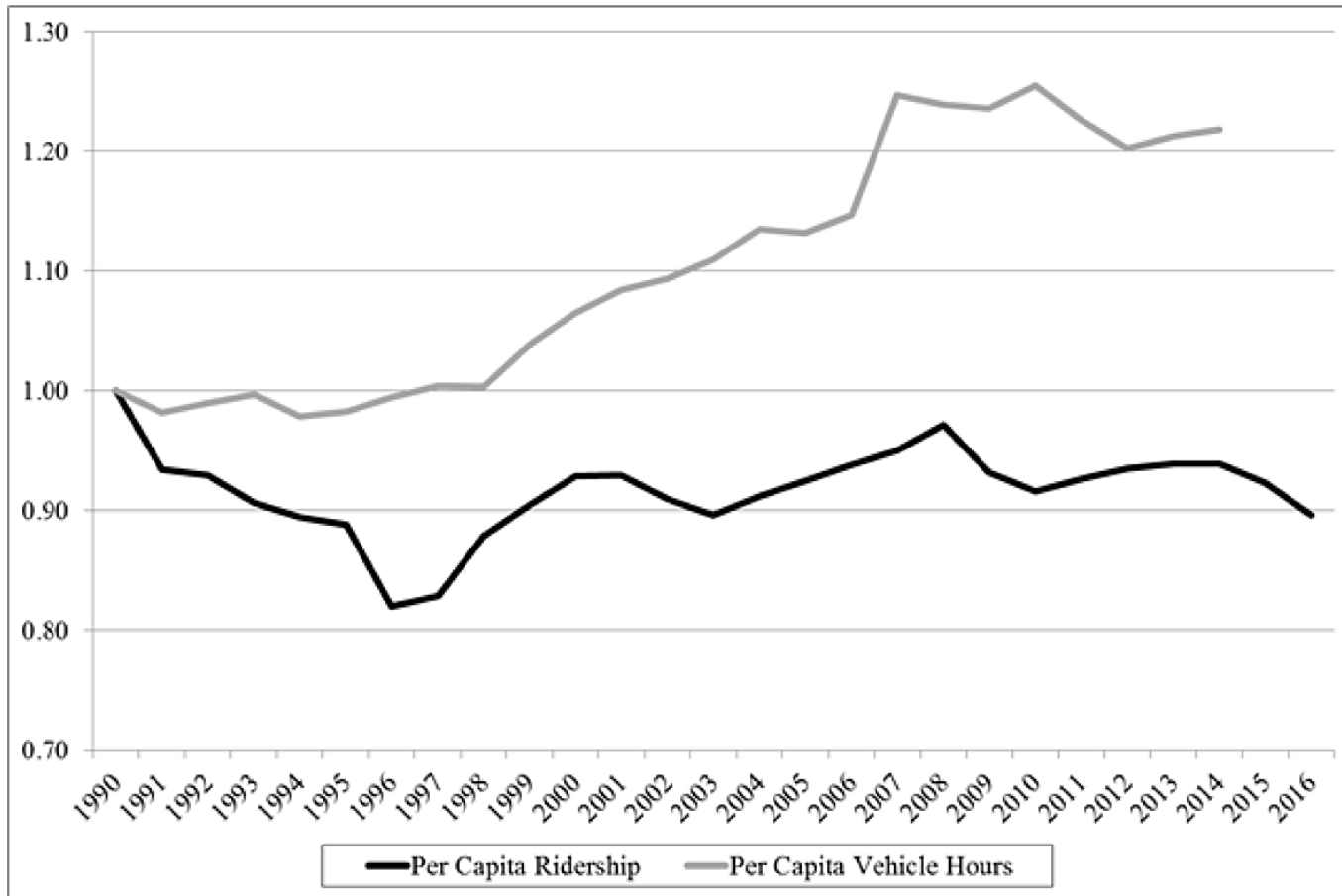

Sources: (a) American Public Transportation Association, Ridership Report (b) American Public Transportation Association, 2016 Public Transportation Fact Book (c) U.S. Census Bureau, National Intercensal Tables.

\section{FIGURE 2.}

Indexed Trends since 1990 in Per Capita Vehicle Hours (through 2014) and Per Capita Ridership (through 2016)

What explains these worrisome trends and what do they mean for transit's future? In this paper we highlight three challenges confronting American public transportation and consider their implications for the future. First, the asymmetry of transit supply and use make it especially vulnerable to changes and disruptions. Second, many of the factors importantly determining transit ridership today, such as private vehicle ownership and use, are largely beyond the control of transit agencies. And third, the political success of the industry is often at odds with its use, which reflects a lack of consensus on its purpose. 


\section{An Asymmetric Industry}

One characteristic of American public transportation is that most people in most places do not use it. The average U.S. resident made 32.2 transit trips in 2016 (Neff and Dickens 2017; U.S. Census Bureau 2016), but the "average resident" is in this case an elusive creature, an artifact of many people never using transit, some using it occasionally, and a few riding a great deal. Chu (2012), for instance, shows that $20 \%$ of the U.S. population lives in neighborhoods where transit is not available, while $60 \%$ lives in a neighborhood with transit service but has not used it in the previous month. Another $11 \%$ of the population takes fewer than 10 transit trips per month, while $8 \%$ takes 10 or more trips. In short, the share of people never using transit was 10 times larger than the share that rode transit 10 times or more per month.

This skewed distribution of transit users and non-users is compounded by their uneven location across space. Most transit service and especially use are found in the nation's oldest and largest metropolitan areas. The 10 largest U.S. transit operators, concentrated overwhelmingly in "legacy" cities like New York, Chicago, Boston, Washington, and San Francisco, carried nearly two-thirds (65\%) of all U.S. transit trips in 2016. The transit operators in the New York urbanized area alone collectively accounted for $41 \%$ of all U.S. transit trips (National Transit Database 2016). Within these transit-rich metropolitan areas, transit provision and use is asymmetric as well-many more trips occur in dense urban areas than in the suburbs. More than half (54\%) of transit users live in neighborhoods with population densities of 10,000 persons per square mile or higher (U.S. Department of Transportation 2009), compared to an overall 2016 U.S. population density of 85 persons per square mile. Finally, transit service provision is temporally asymmetric as well. Compared to automobile travel, transit service and trips are more likely to be made in the peak hour and peak direction than at other times and in other directions (Taylor et al. 2000).

So who are the heavy transit users? Many travel demand analyses over the years have shown that the single largest predictor of public transit use is access to a private vehicle. Put simply, those unable to drive or be driven are far more likely to use transit. This implies two types of transit riders. The first group includes people with higher socioeconomic status who live or work in the small number of American locations where driving is difficult and expensivetypically legacy cities where development densities are high, parking is scarce and priced, and streets are narrow and congested. These people have higher incomes but face high time and monetary costs for driving.

The second group of transit riders may confront the same low price of driving that most Americans face, but cannot drive because they have low incomes or because they have other conditions, be they medical or legal, that prevent them from using automobiles. Of course these two groups overlap: low-income people in places where driving is expensive are particularly likely to ride transit. So even within legacy cities, but especially outside them, transit draws its customers disproportionately from among those too poor, young, or disabled to drive. In practice this has meant that many transit riders are low-income and immigrants from developing countries (discussed further below). Figure 3 compares U.S. transit users with the overall population across a range of socioeconomic and geographic dimensions. 


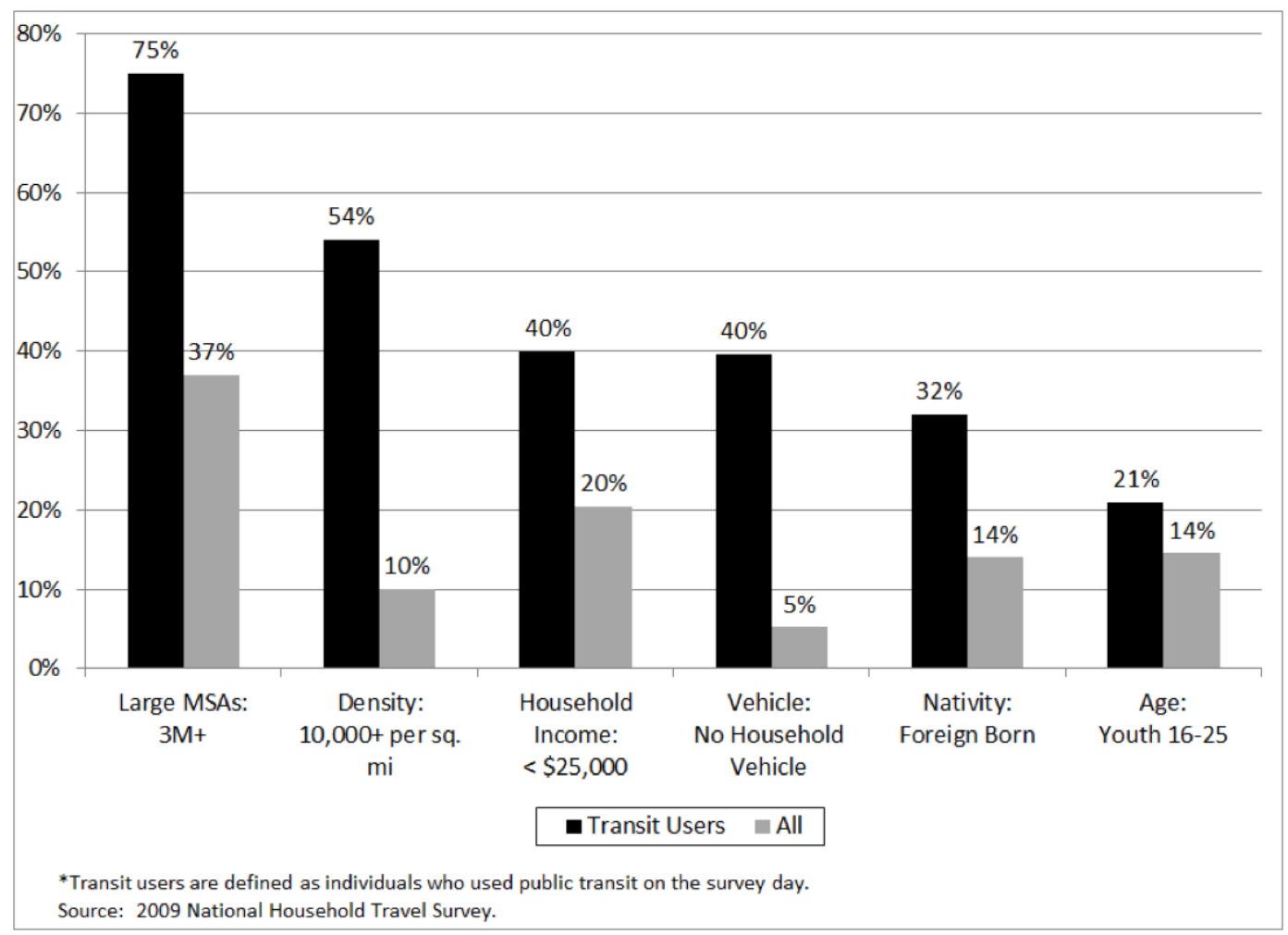

\section{FIGURE 3.}

Comparing Transit Users to the U.S. Population across Six Dimensions

The upshot is that transit use nationwide depends heavily on a relatively small number of frequent transit users in a relatively small number of central cities located in a handful of the largest U.S. metropolitan areas. Given these compounding asymmetries of transit provision and use-among metropolitan areas, within metropolitan areas, by time-of-day and direction, and among travelers - traditional fixed-route, fixed-schedule public transit ridership is especially vulnerable to disruptions to its concentrated base of customers. Even as new, highquality transit services are implemented and transit oriented developments become more common, the demand for transit travel will likely fall if population grows disproportionately outside the largest metropolitan areas or on the suburban fringes within these areas; if households that traditionally drive little get more access to automobiles; if fuel costs dip, cars become more reliable, or other costs of driving decline; or if affordable and convenient chauffeuring and ridesharing services emerge.

\section{Evolving Environments, Markets, and Customers}

Observers have proffered three general explanations for the fall in transit's ridership even as its demand has risen: (1) changes to transit service and pricing, (2) changes in the composition and location of people likely to ride, and (3) changes in competing travel modes. While these reasons are not mutually exclusive, it is important to note that the latter two are largely outside the control of transit managers. 


\section{Changes in the Composition and Location of Likely Transit Riders}

As the long, slow economic recovery trundles along nearly a decade after the 2008 economic crash, job stability and incomes have finally begun to creep up among the poorest U.S. residents, many of whom are among transit's best customers. After years of decline, the mean household incomes in the bottom income quintile have started to rise, an increase nationally of more than $9 \%$ between 2014 and 2016 (U.S. Census Bureau 2017). Current research on transit use in Southern California suggests that auto ownership and access among the poorest quintile of the population has increased substantially since the mid-2000s, and the easier availability of autos could be shifting many of transit's heaviest users to ride less or even abandon transit altogether. If this shift in auto access among poorer households is manifesting nationwide, the effects on ridership could be substantial.

Relatedly, transit is heavily used by immigrants, particularly during their first years in the United States. But immigration has slowed and shifted in recent years (U.S. Department of Homeland Security 2000; 2015), which may be reducing the supply of new transit riders. As immigrants assimilate, they are more likely to move from transit to driving (Blumenberg and Evans 2010; Chatman and Klein 2009; Myers 1996). In addition, more recent immigrants to the United States tend to be more affluent than those who arrived in the late 20th century, and therefore less likely to be heavy transit users on arrival (Pew Research Center 2015). Further, California and some other high-immigrant states have made it easier for undocumented immigrants to obtain driver's licenses (NCSL 2015), which may accelerate transitions from transit to automobiles among immigrants.

Transit ridership is influenced not only by poverty levels, but also by the location of the poor, and it possible that many heavy transit users no longer live close to transit. Cities and suburbs around the United States have promoted transit oriented development (TOD) around bus and particularly rail stations in order to locate more people within walking distance of highquality transit service (Shinkle 2012). TODs have proven popular with high-income workers and may help contribute to the larger back-to-the-city movement among more affluent residents (Baum-Snow and Hartley 2016; Pollack et al. 2010). But this influx of higher-income residents might reduce rather than increase overall ridership. Newer, more affluent residents who arrive in gentrifying transit oriented areas may use transit more than they did previously (and more than if they lived elsewhere), but they may use transit less than the lower-income residents they replace (Dominie 2012). And if the residents they replace end up living farther from quality transit and ride less as a result, then TODs might be successful (in that they will be popular and reduce driving), but also cause a net loss of transit ridership.

Finally, if higher-income residents are more likely over time to live in high-amenity, central-city neighborhoods (Baum-Snow and Hartley 2016; Glaeser and Gottlieb 2006), it also appears that lower-income households may be shifting to more suburban locales. Less than half of the poor now live in central cities, down from 54\% in 2000 (U.S. Census Bureau 2017). So even if poverty has not fallen much, we know that it has suburbanized, meaning poor people now live farther from transit on average (Kneebone and Garr 2010; Kneebone 2014; Zimmerman et al. 2015). So in concert these shifts in the location of wealthier and poorer households may be putting the demography of transit use at odds with its geography. Poor people ride more and people ride more in dense central areas, but poor people are now less likely to be in dense central areas. 


\section{Changes in Competing Travel Modes}

Transit use is sensitive to gasoline prices, with some research showing that gas prices affect transit use more than transit fares do (Cervero 1990). While gas prices have been volatile in recent years, they have generally fallen since the late 2000s and have tended to fall more than rise. However, while falling gas prices may explain part of the recent decline in transit use, we would note that per capita declines in transit ridership began while gas prices were high and climbing.

Despite the best efforts of many transit officials, investments in keeping vehicle travel cheap have likely outpaced investments in making transit travel easier. Los Angeles (LA), for example, has spent a substantial amount on rail since 1990. In many other ways, however, its planning policies continue to subsidize driving. From 1990 to 2009, the city never increased its street parking rates, meaning that the real price of metered street parking fell by more than a third. LA still requires almost every new development to provide parking, and regularly widens roads (Manville et al. 2013; Manville 2017). Nationwide, many TODs are built with abundant parking, meaning that while transit operators are channeling resources into services that work best with relatively higher densities, the surrounding land uses are auto-oriented and may encourage people to drive for most trips (Chatman 2013). In combination these efforts have both contributed to heavy private investments in private vehicle use and inhibited the sort of densities where traditional transit works best.

Finally, over the past decade carshare and bikeshare services have been established in many of the most transit-rich cities in the United States, while transportation network companies (TNCs) have become ubiquitous competitors to both taxis and public transit (National Academies of Sciences, Engineering, and Medicine 2016). The market value of these new companies, particularly Uber, is astonishing, suggesting that venture capitalists envision them as leaders of a technology-driven transformation of urban transportation. TNC use in low-income neighborhoods may be especially relevant for the future of public transit. Assuming they have a smartphone and a credit account (which not all low-income travelers do), users can now purchase automobile trips one at a time-in close to real time and typically at costs well below those charged by taxicabs, particularly for shared ride options. The TNCS in essence allow people to enjoy auto access without the high upfront costs of auto ownership. While these companies, particularly Lyft, have partnered with several transit operators around the United States to offer first mile/last mile connections to line-haul transit service, their net effect on transit use remains uncertain. (To be clear, the effects are certainly knowable but the TNCs have been loath to publicly release their ridership data.) But while TNCs may be taking customers away from public transit today, we note that per capita transit use began falling before the TNCs began aggressively expanding.

All the changes discussed here lie largely outside the control of transit agencies. These agencies can, of course, do much to attract or retain riders: they can improve service frequency and reliability, insure that transit vehicles are clean and safe, provide accurate real-time service information, and price services adroitly. But transit agencies cannot make gas prices, Uber fares, or urban densities go up. They cannot make parking less abundant or immigration more common, and they cannot make poverty more prevalent (nor would we want them to). This means that public transit agencies are in many ways beholden to larger economic and social circumstances that will significantly shape their fate in the years ahead. 


\section{What Purpose Should Public Transit Serve?}

The public transit industry in the United States began as private institutions serving a mostly private purpose. At its height, American public transit was a series of privately owned but publicly regulated monopolies, sometimes operated as loss-leading real estate enterprises. The rise and fall of private transit was dramatic. Transit companies made fortunes for their owners; were decried as sources of urban congestion; helped suburbanize and decentralize American cities; became emblematic (to their detractors) of corrupt cartel capitalism; and ultimately spiraled into insolvency as people abandoned them for cars (Jones 1985; Jackson 1985).

Transit's decline was slowed in the quarter century after the Second World War when municipal agencies resurrected struggling or defunct transit lines and put them under public ownership. Governments have invested heavily in transit since the 1970 s and, as shown in Figure 1, support for public transit service has been particularly strong in the 2000s. But these public entities faced a difficult challenge in taking over transit systems that were designed to make a private profit (and often only indirectly through real estate development) and graft onto them a public purpose (Jones 1985). In some places-Boston, New York, the other legacy cities - this task was not hard. These central cities remained largely built around transit, and transit was essential to how they functioned. Transit in these locations remains essential to the functioning of urban economic agglomerations, and there is a clear public interest in making sure the transit network is extensive and service is frequent. These cities could never rely solely or even largely upon private vehicles and function effectively because they grew up around transit; they retain built environments that simultaneously reward transit use and penalize driving.

In other places, however, transit's role was and still is unclear. Postwar America was defined by falling population densities and rising auto use. In those locations the public sector inserted transit into a world almost uniquely unsuited to it. Operating in mostly dispersed, autooriented environments, transit cannot be the vital cog it once was, or still is in the prewar built environments of legacy cities. In such dispersed, auto-oriented places, transit plays a diminished role; with sparse route networks, long headways, and small mode shares it serves as a back-up transportation system - the public option where the overwhelming majority of people travel and access opportunity privately.

There are inherent limitations to transit's role as a social service. It is difficult for a system that carries mostly low-income people to be extensive and frequent enough to serve riders well, simply because most metropolitan areas do not have that many low-income people who lack auto access. Moreover, in many parts of the United States a transit system that successfully serves low-income riders might be self-undermining as it may allow them to get jobs and money, which they might then use to buy cars. Such a development (which fragmentary evidence suggests may be occurring now) would cause transit ridership to fall, although it is difficult to lament disadvantaged people gaining income.

While transit in many places has defaulted into a social service, many people aspire for transit to be more than that-although what exactly it should be depends on who is being asked. Transit's postwar growth has occurred despite and perhaps because the question of transit's purpose has never quite been settled, especially outside the legacy cities. An impressive 
political coalition has been built upon transit being many things to many people. This approach has made public transit politically stronger and more fiscally solvent than it may have been otherwise, but trying to be so many things to so many interests has also deprived it of a clear mission or comparative advantage.

Consider what transit today is asked to do. Public transportation is variously charged with the missions of reducing traffic congestion, air pollution, and greenhouse gas emissions; of promoting economic revitalization and creating jobs; of reorganizing land use patterns and creating denser, more attractive urban environments; of providing mobility for those without it; and more (Taylor and Morris 2015). This is an ambitious agenda to be sure, and one with the rare ability to win support from environmentalists, labor unions, businesses, and even drivers.

But trouble lurks. Little historical evidence supports the idea that transit can solve these diverse problems. At its height public transportation was criticized as a cause of congestion, not a salve for it. Similarly, where some proponents argue that transit will revitalize urban areas, historically it was an engine of decentralization, pushing population outward into streetcar suburbs. Even if we think that transit today can accomplish different goals than it did in the past, the fact remains that for most of these problems transit is not the best or most cost-effective solution. If we are worried about greenhouse gases, we should tax carbon. If tackling congestion is our priority, we should price peak-hour driving. Income supplements are proven to reduce poverty and in a nation organized around the car, buying poor people automobiles increases mobility far more than building suburban light rail. Transit's advantage is political: it offers a way to solve problems that many people can agree on. Its disadvantage is practical: it may not be a good way to solve those problems.

Of course, the perfect need not be the enemy of the good. Transit may not be the best way to solve these problems, but it is a tool we have that voters are willing to deploy. Here, however, we come full-circle: even if we assume transit can help solve these many social and environmental problems, it can only do so if people ride it. And despite funding transit heavily so it can solve these problems, it has not been gaining riders for decades and has recently been losing them.

It is thus possible, and perhaps likely, that at least some of the longer-term declines in transit productivity and more recent declines in patronage result from a tension between transit's politically popular environmental and economics purposes and its less popular but more tractable social service mission. Put simply, many voters who do not ride transit have strong influence over it, and they may have different ideas for what transit should be than do the many riders who are numerically smaller and often cannot vote. Investments that please the first group may not deliver ridership, while investments that please the second may deliver ridership but be less likely to win funding support. If the second group is also shrinking, the result could explain recent trends in increasing transit supply and falling ridership.

\section{Looking Ahead}

Given these three challenges of demand and service asymmetry, buffeting by exogenous urban and societal changes, and a disconnect between transit politics and transit use, will transit 
patronage continue its recent slide or rebound in the coming years? It depends, both on factors under the purview of transit managers and policy makers as well as those outside of it (Taylor and Fink 2013).

First and perhaps most importantly, ridership will depend on whether we find the political will to intelligently manage private vehicle use by pricing driving at its marginal social cost. If congestion charges, parking charges, emissions charges, and the like become more common, cars will no longer automatically be the default mode for almost all trips in almost all placesparticularly for trips that drivers value less than it costs society to accommodate. This would make public transit considerably more attractive to car owners for some trips, especially in congested areas with limited parking. In addition, adopting these same principles to pricing transit so that fares reflect, even if they do not fully cover, the marginal cost of service would encourage more effective utilization of transit service capacity, increasing productivity (Yoh et al. 2015).

The mode-shifting effects of such pricing policies will be enhanced if transit systems succeed in better integrating real-time information about their services with increasingly popular multi-modal navigation applications on mobile devices, making transit information simple and easy particularly for the majority of the population that currently never rides transit. Such improvements will reduce uncertainty about and the perceived time cost of waiting and transferring for regular riders as well, which would boost ridership (Iseki and Taylor 2009; Yoh et al. 2012).

Second, future transit ridership will depend on whether we focus transit investments in the handful of places where most transit riders currently live. If ridership is transit's primary goal, one could argue that more transit investment should be devoted to shoring up and improving service in the legacy cities rather than expanding new rail services in (for example) places like Arizona or Florida. For this decidedly asymmetric industry, the New York Metropolitan Transportation Authority (MTA) needs enormous sums of money to rebuild and upgrade its aging infrastructure, which moves more than $35 \%$ of the nation's transit passengers each day (National Transit Database 2017). How effectively this industry behemoth rebuilds itself will go a long way toward determining the future of American public transit. Big city rail systems in Boston, Chicago, Washington, and elsewhere will need to similarly upgrade. And heavily patronized bus systems in places like New York, Los Angeles, Philadelphia, and Seattle will need to maintain and modernize their vehicle stocks as well.

There are significant political obstacles to focusing public transit investments so narrowly, as public finance politics favor spreading expenditures across many voters rather than concentrating them geographically on a few beneficiaries. In addition, while transit might work best in legacy cities, it remains a vital social service for disadvantaged households with little or no access to automobiles in cities large and small nationwide, which both politically and morally militates against concentrating transit service in a few locations. In other words, there is an argument that ridership isn't everything and that in the name of helping vulnerable people we may need to continue heavily subsidizing some low-productivity systems.

Third, ridership will depend on whether thriving, densely developed, congested places can continue to flourish while becoming denser, more congested, and transit friendly. It will 
also depend on whether service increases and improves in these expanding transit-friendly locations where patronage is already high, or whether political pressure will instead steer resources toward adding relatively unproductive transit service in far-flung, low-density, autofriendly, transit-hostile suburbs where most population growth is occurring.

From one perspective, the odds here seem long. Transit-friendly environments in the United States are relatively scarce and continue to decline in relative terms, notwithstanding the growing popularity of transit oriented developments. A recent study of population change in urban, suburban, and rural neighborhood types (based on built form and transportation system characteristics) across the United States found that over half of all U.S. population growth since 2000 has been in the most sprawling, least transit-friendly suburban developments (Voulgaris et al. 2017). Given this seemingly relentless suburbanization, the relative role of traditional fixed-route, fixed-schedule public transit will likely continue to diminish over time, even if absolute patronage levels rebound in the coming decade.

But transit need not be conceived of so narrowly. Traditional transit can also be viewed as one of the oldest and highest capacity forms of shared mobility, part of a larger constellation of options that range from shared ride vehicle services in far-flung suburbs to bus and rail modes in built-up urban areas. If we view transit in this more holistic way, the role of transit in urban mobility may well wax in the decades ahead.

Finally, the future of transit patronage will also depend on whether incomes and auto access in low-income households continue to climb and whether immigration from poor countries remains relatively low. This factor is obviously beyond the purview of transit officials and it is far from clear that increased ridership through this channel is desirable. Given a choice between more transit use and less poverty, most people prefer the latter. At the same time, immigration from poorer countries could increase in the coming years depending on political and economic circumstances both at home and abroad. An influx of lower-income people seeking opportunity could breathe new life into transit use.

In summary, the future of public transit depends on many factors. Some of these are directly controlled by transit agencies, others are more broadly within the purview of elected officials and transportation policy makers, while still others are largely beyond the reach of transportation policy. Regardless, popular and political aspirations for transit exceed both realistic expectations for the mode and our willingness to make the difficult choices needed to see it thrive. We aspire for transit to be an engine of change, but it is more often a recipient of circumstances. This fact suggests that we need to fundamentally change those circumstances in order to change transit, not the other way around. When we want transit to change our economy, environment, or landscape, we misunderstand both the source of our transportation problems and transit's potential as a solution. The contemporary United States is designed for and dominated by automobiles. This arrangement has caused undeniable problems, but expecting transit to solve these problems on its own is quixotic. Excess driving is not a result of people failing to take transit; it is a result of people driving. Therefore, the problems of the car will not be solved by transit. They will be solved when public policy confronts the car. If and when that happens, transit can once again play a vital role in American urban transportation. 


\section{Acknowledgement}

The authors thank UCLA Master of Public Policy student Tiffany Chu for her collection and analysis of some of the data presented in this paper.

\section{References}

American Public Transportation Association. Various dates. Quarterly Ridership Reports.

Baum-Snow, N., and D. Hartley. 2016. Causes and Consequences of Central Neighborhood Change, 1970-2010. Chicago: Federal Reserve Bank of Chicago.

Blumenberg, E., and A. E. Evans. 2010. "Planning for Demographic Diversity: The Case of Immigrants and Public Transit." Journal of Public Transportation, 13(2): 23-45. doi: 10.5038/2375-0901.13.2.2.

Cervero, R. 1990. "Transit pricing research: A review and synthesis." Transportation, 17(2): 117139.

Chatman, D. 2013. "Does TOD Need the T? On the Importance of Factors Other Than Rail Access." Journal of the American Planning Association, 79(1): 17-31. doi: 10.1080/01944363.2013.791008.

Chatman, D. G., and N. Klein. 2009. "Immigrants and Travel Demand in the United States: Implications for Transportation Policy and Future Research." Public Works Management \& Policy, 13(4): 312-327. doi: 10.1177/1087724X09334633.

Chu, X. 2012. An Assessment of Public Transportation Markets Using NHTS Data. Final Report. National Center for Transit Research at CUTR, University of South Florida, Tampa.

Dominie, W. 2012. Is Just Growth Smarter Growth? The Effects of Gentrification on Transit Ridership and Driving in Los Angeles' Transit Station Area Neighborhoods. University of California, Los Angeles.

Glaeser, E. L., and J. D. Gottlieb. 2006. "Urban Resurgence and the Consumer City." Urban Studies, 43(8): 1275-99. doi: 10.1080/00420980600775683.

Iseki, H., and B. D. Taylor. 2009. "Not all transfers are created equal: towards a framework relating transfer connectivity to travel behavior." Transport Reviews, 29(6): 777-800.

Jackson, K. 1985. Crabgrass Frontier: The Suburbanization of the United States. Oxford, UK: Oxford University Press.

Jones, D. W., Jr. 1985. Urban Public Transit: An Economic and Political History. Englewood Cliffs, NJ: Prentice Hall.

Kneebone, E. 2014. The Growth and Spread of Concentrated Poverty, 2000 to 2008-2012. Washington, DC: The Brookings Institution. https://www.brookings.edu/interactives/thegrowth-and-spread-of-concentrated-poverty-2000-to-2008-2012/\#/M10420. 
Kneebone, E., and E. Garr. 2010. The Suburbanization of Poverty: Trends in Metropolitan America, 2000 to 2008. Washington, DC: The Brookings Institution. https://www. brookings.edu/research/the-suburbanization-of-poverty-trends-in-metropolitan-america2000-to-2008/.

Manville, M. 2017. "Automatic street widening: Evidence from a highway dedication law." Journal of Transport and Land Use, 10(1): 375-393.

Manville, M., and B. Cummins. 2015. "Why do voters support public transportation? Public choices and private behavior." Transportation, 42(2): 303-332.

Manville, M., A. Beata, and D. Shoup. 2013. "Turning Housing Into Driving: Parking Requirements and Density in Los Angeles and New York." Housing Policy Debate, 23(2):350-375. doi: 10.1080/10511482.2013.767851.

Myers, D. 1996. "Changes over Time in Transportation Mode for Journey to Work: Effects of Aging and Immigration." Decennial Census Data for Transportation Planning: Case Studies and Strategies for 2000, 2(13): 84-99. Washington, DC: Transportation Research Board.

National Academies of Sciences, Engineering, and Medicine. 2016. Between Public and Private Mobility: Examining the Rise of Technology-Enabled Transportation Services. Transportation Research Board Special Report 319. Washington, DC: The National Academies Press. doi: $10.17226 / 21875$.

National Transit Database. Various years. Washington, DC: Federal Transit Administration.

NCSL. 2015. "States Offering Driver's Licenses to Immigrants." Washington, DC: National Conference of State Legislatures. http://www.ncsl.org/research/immigration/statesoffering-driver-s-licenses-to-immigrants.aspx.

Neff, J., and M. Dickens. 2017. 2016 Public Transportation Fact Book, 67th Edition. Washington, DC: American Public Transportation Association.

Pew Research Center. 2015. Modern Immigration Wave Brings 59 Million to U.S., Driving Population Growth and Change Through 2065: Views of Immigration's Impact on U.S. Society Mixed. Hispanic Trends, September 28. http://www.pewhispanic.org/ files/2015/09/2015-09-28_modern-immigration-wave_REPORT.pdf.

Pollack, S., B. Bluestone, and C. Billingham. 2010. Maintaining Diversity In America's TransitRich Neighborhoods: Tools for Equitable Neighborhood Change. Dukakis Center for Urban and Regional Policy, Northeastern University.

Shinkle, D. 2012. Transit-Oriented Development in the States. Washington, DC: National Conference of State Legislatures. http://www.ncsl.org/Documents/transportation/TOD_ Final.pdf.

Taylor, B. D., and C. N. Y. Fink. 2013. "Explaining transit ridership: What has the evidence shown?" Transportation Letters: The International Journal of Transportation Research, 5(1): 15-26. doi: 10.1179/1942786712Z.0000000003. 
Taylor, B. D., M. Garrett, and H. Iseki. 2000. "Measuring cost variability in provision of transit service." Transportation Research Record: Journal of the Transportation Research Board, 1735: 101-112. doi: 10.3141/1735-13.

Taylor, B. D., D. Miller, H. Iseki, and C. Fink. 2009. "Nature and/or nurture? Analyzing the determinants of transit ridership across US urbanized areas." Transportation Research Part A: Policy and Practice, 43(1): 60-77. doi: 10.1016/j.tra.2008.06.007.

Taylor, B. D., and E. A. Morris. 2015. "Public transportation objectives and rider demographics: are transit's priorities poor public policy?" Transportation, 42(2): 347-367. doi: 10.1007/ s11116-014-9547-0.

U.S. Census Bureau. 2011. Table 1. Intercensal Estimates of the Resident Population by Sex and Age for the United States: April 1, 2000 to July 1, 2010 (US-EST00INT-01). Population Division.

U.S. Census Bureau. 2016. Table 1. Annual Estimates of the Resident Population for the United States, Regions, States, and Puerto Rico: April 1, 2010 to July 1, 2016 (NST-EST2016-01). Population Division.

U.S. Census Bureau. 2017. Current Population Survey, Annual Social and Economic Supplement.

U.S. Department of Homeland Security. 2000. 2000 Yearbook of Immigration Statistics. Washington, DC: Office of Immigration Statistics.

U.S. Department of Homeland Security. 2015. 2015 Yearbook of Immigration Statistics. Washington, DC: Office of Immigration Statistics.

U.S. Department of Transportation. 2009. Summary of Travel Trends: 2009 National Household Travel Survey. Washington, DC: U.S. Department of Transportation, Federal Highway Administration. http://nhts.ornl.gov/2009/pub/stt.pdf.

Voulgaris, C. T., B. D. Taylor, E. Blumenberg, A. Brown, and K. Ralph. 2017. "Synergistic neighborhood relationships with travel behavior: An analysis of travel in 30,000 US neighborhoods." Journal of Transport and Land Use, 10(1): 437-461. doi: 10.5198/ jtlu.2016.840.

Yoh, A., B. D. Taylor, and J. Gahbauer. 2015. "Does Transit Mean Business? Reconciling Economic, Organizational, and Political Perspectives on Variable Transit Fares." Public Works Management \& Policy, 21(2): 157-172. doi: 10.1177/1087724X15616816.

Yoh, A., H. Iseki, M. Smart, and B. D. Taylor. 2012. "Hate to Wait: Effects of Wait Time on Public Transit Travelers' Perceptions." Transportation Research Record: Journal of the Transportation Research Board, 2216: 116-124. doi: 10.3141/2216-13.

Zimmerman, R., C. E. Restrepo, H. B. Kates, and R. Joseph. 2015. Suburban Poverty, Public Transit, Economic Opportunities and Social Mobility. Final Report. Robert F. Wagner Graduate School of Public Service, New York University. 


\section{About the Authors}

Michael MAnville, Ph.D. (mmanvill@ucla.edu) is assistant professor of Urban Planning at the UCLA Luskin School of Public Affairs, and a faculty affiliate of the UCLA Institute of Transportation Studies. His research focuses on the relationships between transportation and land use, as well as on local public finance.

BRIAN D. TAYLOR, Ph.D. (btaylor@ucla.edu) is professor of Urban Planning, director of the Institute of Transportation Studies, and director of the Lewis Center for Regional Policy Studies at the UCLA Luskin School of Public Affairs. His research and teaching center on travel behavior as well as transportation equity, finance, history, and politics.

Evelyn Blumenberg, PH.D. (eblumenb@ucla.edu) is professor of Urban Planning at the UCLA Luskin School of Public Affairs. Her research focuses on the effects of urban structurethe spatial location of residents, employment, and services-on economic outcomes for immigrants and low-wage workers. 